\title{
Synthesis and Crystal Structure of Dinuclear Cadmium(II) Complex with Dipodal Ligand
}

\author{
Youngjin Kang, ${ }^{\dagger}$ Suk-Hee Moon, ${ }^{\star}$ Jong Chul Byun, ${ }^{\S, *}$ and Ki-Min Park ${ }^{*}$ \\ Department of Chemistry (WCU) and Research Institute of Natural Science, Gyeongsang National University, \\ Jinju660-701, Korea. *E-mail: kmpark@gnu.ac.kr \\ ${ }^{\dagger}$ Division of Science Education, Kangwon National University, Chuncheon 200-701, Korea \\ ${ }^{*}$ Subdivision of Food Science, Kyungnam College of Information and Technology, Busan 616-701, Korea \\ ${ }^{\S}$ Department of Chemistry, College of Natural Sciences, Jeju National University, Jeju 690-756, Korea \\ ${ }^{*}$ E-mail: jchbyun@cheju.ac.kr \\ Received June 28, 2010, Accepted August 18, 2010
}

Key Words: Cadmium(II) halide, Coordination chemistry, Dinuclear complex, Dipodal ligand, Crystal structure

During the last four decades, the chemistry of macrocyclic and non-cyclic polyethers has attracted an increasing attention because of their selective complexation, cation transport and enzyme chemistry. ${ }^{1-5}$ In the field of coordination chemistry, generally, non-cyclic, crown-type polyether affords the low complexation ability because of its conformational freedom while macrocyclic polyethers such as 18 -crown- 6 show the excellent complexing ability. However, the open chain oligoethylene glycols, so-called podands, with rigid aromatic donor end-groups at the both ends of the oligo(ethylene glycol) backbone have been reported on the considerable enhancement of complexing stabilities. ${ }^{4 \mathrm{c}}$ Especially, the 1,13-bis(8-quinolyl)1,4,7,10,13-pentaoxatridecane (L) has been spotlighted as a key podand because of its attractive characteristics to form a pseudo cyclic complex with metal ion by the intra-stacking interaction between two quinoline end-groups. ${ }^{6}$ According to our and other's works on complexation of $\mathbf{L}$ against the transition metal ions, ${ }^{7} \mathbf{L}$ was also found to form the stable complexes with $\mathrm{Ag}^{+}$or $\mathrm{Hg}^{2+}$ ions in solid state owing to two quinoline end-groups of $\mathbf{L}$.

Recently, we have reported the unique pseudo-cyclic $\mathrm{Cd}(\mathrm{II})$ complexes $\left[\mathrm{Cd}(\mathbf{L})\left(\mathrm{H}_{2} \mathrm{O}\right)\left(\mathrm{CH}_{3} \mathrm{OH}\right)\right]\left(\mathrm{ClO}_{4}\right)_{2}(\mathbf{1 a})$ and $[\mathrm{Cd}(\mathbf{L})$ $\left.\left(\mathrm{H}_{2} \mathrm{O}\right)\left(\mathrm{NO}_{3}\right)\right]\left(\mathrm{NO}_{3}\right)(\mathbf{1 b})$, in which the dipodal receptor $(\mathbf{L})$ with quinoline end-groups wrapped around the cadmium atom in a helical mode, obtained by self-assembly of the dipodal ligand (L) and $\mathrm{CdX}_{2}\left(\mathrm{X}=\mathrm{ClO}_{4}\right.$ and $\left.\mathrm{NO}_{3}\right)$ (Figure $\mathrm{S} 1$ in Supporting Information). ${ }^{8}$ As a part of ongoing efforts for the complexation of $\mathbf{L}$ against transition metal ions, we prepared another Cd(II) complex with chloride anion. Herein, we report crystal structure and thermal behavior of dinuclear Cd(II) complex (2).

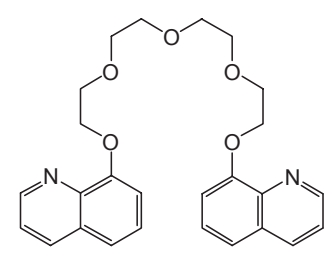

L

The colorless crystal of $\mathbf{2}$ was obtained by slow diffusion of a $\mathrm{MeCN}$ solution of $\mathbf{L}$ layered with a $\mathrm{MeOH}$ solution of $\mathrm{CdCl}_{2}$.
2.5 $\mathrm{H}_{2} \mathrm{O}$. Single-crystal X-ray diffraction study revealed that 2 is the $1: 2(\mathbf{L}: \mathbf{C d})$ complex of formula of $\left[\mathrm{Cd}_{2}(\mathbf{L}) \mathrm{Cl}_{4}\right] \cdot 2\left(\mathrm{H}_{2} \mathrm{O}\right)$. $0.5\left(\mathrm{CH}_{3} \mathrm{OH}\right) \cdot 0.5\left(\mathrm{CH}_{3} \mathrm{CN}\right)$, in which rhomboidal $\mathrm{Cd}-\left(\mu_{2}-\mathrm{Cl}\right)_{2}-$ $\mathrm{Cd}$ unit is accommodated inside the dipodal ligand $\mathbf{L}$ as shown in Fig. 1. In the asymmetric unit of $\mathbf{2}$, there are two crystallographically independent $\mathrm{Cd}$ atoms which adopt the distorted pentagonal bipyramidal geometries with seven-coordinate number, being bound to three $\mathrm{O}$ and one $\mathrm{N}$ donors of $\mathbf{L}$ and three $\mathrm{Cl}$ atoms. The $\mathrm{O}_{3} \mathrm{~N}$ donors of $\mathbf{L}$ and one bridging $\mathrm{Cl}$ atom $(\mathrm{Cl} 3$

(a)

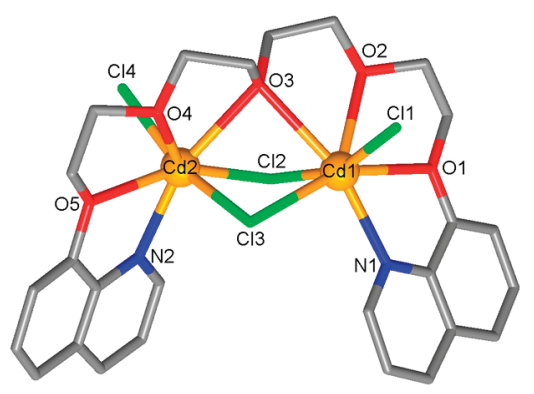

(b)

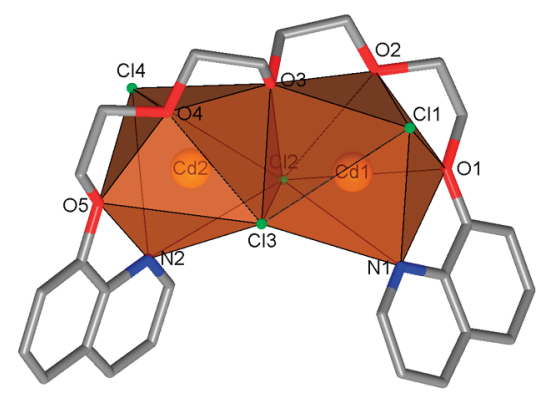

(c)

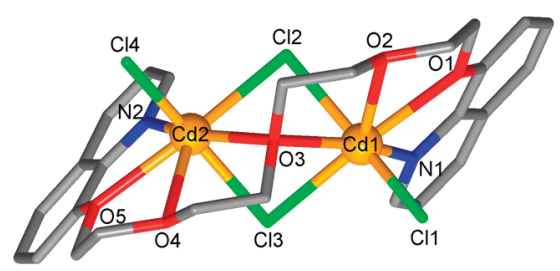

Figure 1. The crystal structure of 2: general view represented by (a) ball-and-stick and (b) combined stick/polyhedral model, and (c) top view. Hydrogen atoms and solvent molecules are omitted for clarity. 
for $\mathrm{Cd} 1$ and $\mathrm{Cl} 2$ for $\mathrm{Cd} 2$ ) define the equatorial plane with the axial positions occupied by the terminal and bridging $\mathrm{Cl}$ atoms ( $\mathrm{Cl} 1$ and $\mathrm{Cl} 2$ for $\mathrm{Cd} 1$ and $\mathrm{Cl} 4$ and $\mathrm{Cl} 3$ for $\mathrm{Cd} 2$ ). The bond angles of the axial $\mathrm{Cl}_{\text {terminal- }} \mathrm{Cd}-\mathrm{Cl}_{\text {bridging }}$ bonds are $160.43(7)^{\circ}$ for $\mathrm{Cd} 1$ and $162.43(7)^{\circ}$ for $\mathrm{Cd} 2$ (Table 2). The polyhedrons represented the geometries of two $\mathrm{Cd}$ atoms are face-sharing to each other (Fig. 1b). $\mathrm{Cd} 1$ and $\mathrm{Cd} 2$ atoms are deviated from each equatorial plane with $0.175(2)$ and $0.211(2) \AA$, respectively.

The Cd-Cl $l_{\text {bridging }}$ bond lengths (2.5370(17) and 2.6764(18) $\AA$ ) are longer than those (2.4523(18) and 2.456(2) $\AA$ ) of Cd-Cl terminal. $_{\text {t }}$.

Table 1. Crystallographic data and structure refinement for $\mathbf{2}$

\begin{tabular}{ll}
\hline Chemical formula & $\mathrm{C}_{27.5} \mathrm{H}_{35.5} \mathrm{Cd}_{2} \mathrm{Cl}_{4} \mathrm{~N}_{2.5} \mathrm{O}_{7.5}$ \\
Formula weight & 887.68 \\
$T(\mathrm{~K})$ & $173(2)$ \\
Crystal system & Triclinic \\
Space group & $\mathrm{P}-1$ \\
$a(\AA)$ & $8.8709(8)$ \\
$b(\AA)$ & $12.9802(12)$ \\
$c(\AA)$ & $16.4221(15)$ \\
$\alpha\left({ }^{\circ}\right)$ & $96.906(2)$ \\
$\beta\left({ }^{\circ}\right)$ & $100.032(2)$ \\
$\gamma\left({ }^{\circ}\right)$ & $93.375(2)$ \\
$V\left(\AA^{3}\right)$ & $1842.3(3)$ \\
$Z$ & 2 \\
Absorption coefficient $\left(\mathrm{mm}^{-1}\right)$ & 1.488 \\
$F(000)$ & 884 \\
Crystal size (mm $\left.{ }^{3}\right)$ & $0.40 \times 0.08 \times 0.08$ \\
$\theta$ range $\left({ }^{\circ}\right)$ & 1.27 to 26.00 \\
Reflections collected/Unique & $10559 / 7097$ \\
Absorption correction & Semi-empirical from equivalents \\
No. variables & $(\mathrm{SADABS})$ \\
Refl./para. ratio & 442 \\
Goodness-of-fit on $F^{2}$ & 16.06 \\
Final $R_{1}, w R_{2}[I>2 \sigma(I)]$ & 1.033 \\
$($ all data) & $0.0564,0.1526$ \\
\hline & $0.0817,0.1757$ \\
&
\end{tabular}

Table 2. Selected bond lengths $(\AA)$, bond angles $\left({ }^{\circ}\right)$ and torsion angles $\left(^{\circ}\right)$ for 2

\begin{tabular}{llll}
\hline $\mathrm{Cd} 1-\mathrm{N} 1$ & $2.351(6)$ & $\mathrm{Cd} 1-\mathrm{O} 1$ & $2.530(5)$ \\
$\mathrm{Cd} 1-\mathrm{O} 2$ & $2.611(5)$ & $\mathrm{Cd} 1-\mathrm{O} 3$ & $2.689(5)$ \\
$\mathrm{Cd} 1-\mathrm{Cl1}$ & $2.4523(18)$ & $\mathrm{Cd} 1-\mathrm{Cl} 2$ & $2.5370(17)$ \\
$\mathrm{Cd} 1-\mathrm{Cl} 3$ & $2.6724(18)$ & $\mathrm{Cd} 2-\mathrm{O} 3$ & $2.648(5)$ \\
$\mathrm{Cd} 2-\mathrm{O} 4$ & $2.594(5)$ & $\mathrm{Cd} 2-\mathrm{O} 5$ & $2.522(5)$ \\
$\mathrm{Cd} 2-\mathrm{N} 2$ & $2.358(6)$ & $\mathrm{Cd} 2-\mathrm{Cl} 2$ & $2.6822(18)$ \\
$\mathrm{Cd} 2-\mathrm{Cl} 3$ & $2.5564(7)$ & $\mathrm{Cd} 2-\mathrm{Cl} 4$ & $2.456(2)$ \\
$\mathrm{C} 11-\mathrm{Cd} 1-\mathrm{Cl} 2$ & $160.43(7)$ & $\mathrm{Cl3}-\mathrm{Cd} 2-\mathrm{Cl} 4$ & $162.43(7)$ \\
$\mathrm{Cl2}-\mathrm{Cd} 1-\mathrm{Cl} 3$ & $84.71(5)$ & $\mathrm{Cl2}-\mathrm{Cd} 2-\mathrm{Cl} 3$ & $84.22(6)$ \\
$\mathrm{Cd} 1-\mathrm{Cl} 2-\mathrm{Cd} 2$ & $86.59(5)$ & $\mathrm{Cd} 1-\mathrm{Cl} 3-\mathrm{Cd} 2$ & $86.32(5)$ \\
$\mathrm{C} 8-\mathrm{O} 1-\mathrm{C} 10-\mathrm{C} 11$ & $-173.2(6)$ & $\mathrm{O} 1-\mathrm{C} 10-\mathrm{C} 11-\mathrm{O} 2$ & $-56.3(8)$ \\
$\mathrm{C} 10-\mathrm{C} 11-\mathrm{O} 2-\mathrm{C} 12$ & $-173.5(7)$ & $\mathrm{C} 11-\mathrm{O} 2-\mathrm{C} 12-\mathrm{C} 13$ & $-179.9(6)$ \\
$\mathrm{O} 2-\mathrm{C} 12-\mathrm{C} 13-\mathrm{O} 3$ & $66.2(8)$ & $\mathrm{C} 12-\mathrm{C} 13-\mathrm{O} 3-\mathrm{C} 14$ & $89.6(7)$ \\
$\mathrm{C} 13-\mathrm{O} 3-\mathrm{C} 14-\mathrm{C} 15$ & $91.7(7)$ & $\mathrm{O} 3-\mathrm{C} 14-\mathrm{C} 15-\mathrm{O} 4$ & $66.4(8)$ \\
$\mathrm{C} 14-\mathrm{C} 15-\mathrm{O} 4-\mathrm{C} 16$ & $-178.6(6)$ & $\mathrm{C} 15-\mathrm{O} 4-\mathrm{C} 16-\mathrm{C} 17$ & $-173.0(6)$ \\
$\mathrm{O} 4-\mathrm{C} 16-\mathrm{C} 17-\mathrm{O} 5$ & $-56.8(8)$ & $\mathrm{C} 16-\mathrm{C} 17-\mathrm{O} 5-\mathrm{C} 18$ & $-177.0(6)$ \\
\hline
\end{tabular}

The observed $\mathrm{Cd}-\mathrm{Cl}$ distances including the bridging and terminal chlorides are similar to those of literature ${ }^{9}$ which sevencoordinate dinuclear cadmium(II) complex bridged by two $\mathrm{Cl}$ and one $\mathrm{O}$ atoms. The bond lengths and angles between the $\mathrm{Cd}$ center and the $\mathrm{N} / \mathrm{O}$ donor atoms of $\mathbf{L}$ except bridging $\mathrm{O}$ atom (O3) are similar to those of Cd complexes (1a and $\mathbf{1 b}$ ) of $\mathbf{L}$ reported previously. ${ }^{8}$ The Cd-O3 distances (av. 2.669(5) $\AA$ ) are slightly longer than those of the other Cd-O (av. 2.564(5) $\AA$ ), also comparable with the value of literature.

In the crystal structure of $\mathbf{2}$, two $\mathrm{Cd}$ atoms are bridged by one oxygen atom of $\mathbf{L}$ and two chloride anions (Fig. 1). The Cd $\cdots$ Cd seperation is $3.5807(7) \AA$, which is longer than the sum of van der Waals radii of cadmium $(3.2 \AA),{ }^{10}$ indicating no effective intermetallic interaction. However, this distance is shorter than those (3.76-4.08 $\AA$ ) of other Cd(II) complexes ${ }^{11}$ bridged by two chloride atoms because two $\mathrm{Cd}$ atoms of $\mathbf{2}$ may be bridged by oxygen $(\mathrm{O} 3)$ and two chloride atoms. The oxygen bridging leads the rhomboid consisting of $\mathrm{Cd}-\left(\mu_{2}-\mathrm{Cl}\right)_{2}-\mathrm{Cd}$ to bend with four corner angles of the 84.22(6) - 86.59(5) A range. The dihedral angles between two planes through $\mathrm{Cd}-\left(\mu_{2}-\mathrm{Cl}\right)_{2}$ and two planes through $\mathrm{Cd}-\left(\mu_{2}-\mathrm{Cl}\right)-\mathrm{Cd}$ are $44.69(4)^{\circ} 45.46(5)^{\circ}$, respectively. Moreover, the rhomboid $\mathrm{Cd}-\left(\mu_{2}-\mathrm{Cl}\right)_{2}-\mathrm{Cd}$ is approximately bisected by the plane consisting of two $\mathrm{Cd}$ atoms and one $\mathrm{O}$ atom $(\mathrm{O} 3)$ of $\mathbf{L}$, from which $\mathrm{Cl} 2$ and $\mathrm{Cl} 3$ is apart with 1.760(3) and 1.748(3) $\AA$, respectively (Fig. 1c).

All conformations of $\mathrm{O}-\mathrm{C}-\mathrm{C}-\mathrm{O}$ of $\mathbf{L}$ are gauche, and those of C-C-O-C or C-O-C-C are trans except the conformations including $\mathrm{O} 3$ atom, which have the torsion angles of 89.6(7) and $91.7(7)^{\circ}$ (See Fig. 1c and Table 2). These exceptional conformations maybe occur because $\mathrm{O} 3$ atom is coordinated to two Cd atoms accommodated by $\mathbf{L}$. Such conformation of $\mathbf{L}$ in $\mathbf{2}$ are similar to those of tetraethylene glycol dimethyl ether ligand accommodated two cadmium ions bridged by two chloride and one oxygen atoms of ligand, ${ }^{9}$ suggesting that this conformation of $\mathbf{L}$ is fit to accommodate the bridging dicadmium ions.

In the packing structure, as shown in Fig. 2, the quinoline end-groups of adjacent molecules related by the inversion center interact via the intermolecular $\pi-\pi$ stackings with a distances

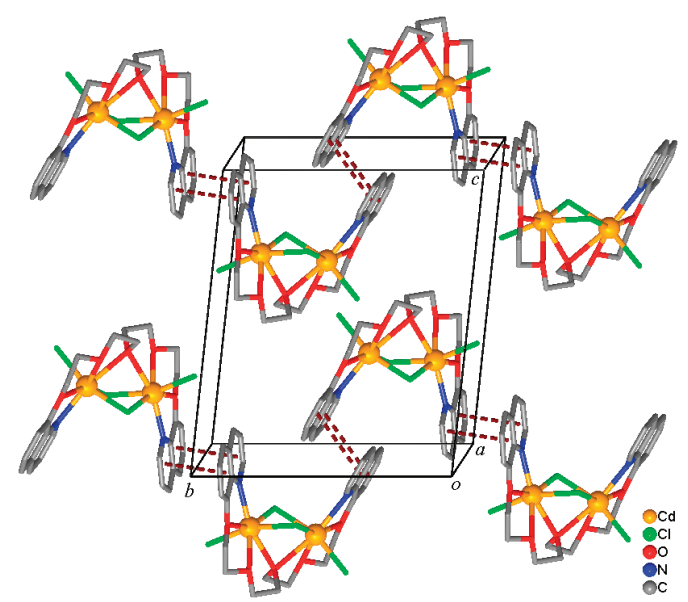

Figure 2. Perspective molecular packing diagram of $\mathbf{1}$ showing the $\pi-\pi$ interactions between quinoline end-groups. Hydrogen atoms and solvent molecules are omitted for clarity. 


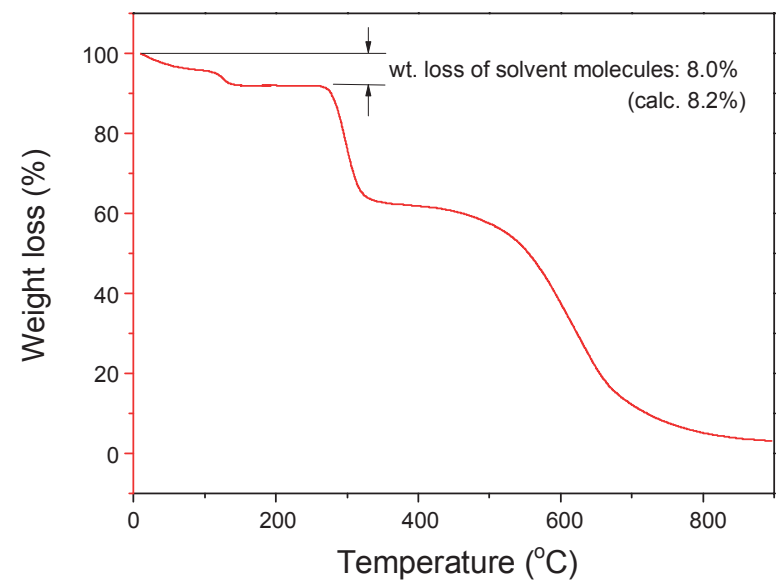

Figure 3. TGA curve for 2.

of 3.405(9) and 3.362(7) $\AA$ to form pseudo 1-D polymer and to contribute to stabilization of complex, of which the evidence for thermal stability can be found in TG analysis. In the unit cell, a lot of solvent molecules such as water, acetonitrile and methanol with the disordered form only occupied the void between complexes. There is no evidence of intermolecular interactions between solvent molecules and complex.

Thermogravimetric analysis shows that the dinuclear complex 2 releases the solvent molecules at room temperature (Fig. 3). The first weight loss (-8.0\%) from room temperature to $140{ }^{\circ} \mathrm{C}$ corresponds to the complete loss of the solvent molecules. After the release of all solvent molecules, however, $\mathbf{2}$ is stable up to $260^{\circ} \mathrm{C}$, and followed by the sequent release of the ligand and the chloride atoms. As mentioned above, the stabilization of complex may be originated by the intermolecular $\pi-\pi$ stackings.

In summary, the preparation and structural characterization of the discrete dinuclear cadmium(II) complex with the formula $\left[\mathrm{Cd}(\mathbf{L})\left(\mu_{2}-\mathrm{Cl}\right)_{2} \mathrm{Cl}_{2}\right] \cdot 2\left(\mathrm{H}_{2} \mathrm{O}\right) \cdot 0.5\left(\mathrm{CH}_{3} \mathrm{OH}\right) \cdot 0.5\left(\mathrm{CH}_{3} \mathrm{CN}\right)(2)$ obtained from the reaction of $\mathrm{CdCl}_{2} \cdot 2.5 \mathrm{H}_{2} \mathrm{O}$ and podal ligand (L) with quinoline end-groups has been reported. In $\mathbf{2}$, two cadmium ions are triply bridged by two chloride and one donor atoms of ligand $\mathbf{L}$ and adopt distorted pentagonal bipyramidal geometries with seven coordinations. It is notable that example of discrete dinuclear complex which one podal ligand accommodates simultaneously two metal ions is very rare.

\section{Experimental Section}

All commercial reagents including solvents were of analytical reagent grade where available. The IR spectra were recored on a VERTEX 80v FT-IR spectrometer with $\mathrm{KBr}$ pellet in the range $4000 \sim 400 \mathrm{~cm}^{-1}$. Elemental analysis was carried out on a CHNS-932 elemental analyzer after the free solvent molecules were removed in vacuo because they are released immediately when crystals were removed from mother liquor. Thermogravimetric analysis (TGA) was performed under nitrogen on a SDT Q600 thermogravimetric analyzer. The sample was heated using a $10{ }^{\circ} \mathrm{C} / \mathrm{min}$ heating rate from 10 to $900{ }^{\circ} \mathrm{C}$.

Preparation of 1,13-bis(8-quinolyl)-1,4,7,10,13-pentaoxatridecane $(\mathbf{L})$. $\mathbf{L}$ was synthesized according to literature pro- cedure. $^{4 \mathrm{c}}$

Preparation of $\left[\mathrm{Cd}_{2}(\mathrm{~L}) \mathrm{Cl}_{4}\right] \cdot 2\left(\mathrm{H}_{2} \mathrm{O}\right) \cdot \mathbf{0 . 5}\left(\mathrm{CH}_{3} \mathrm{OH}\right) \cdot \mathbf{0 . 5}\left(\mathrm{CH}_{3}\right.$ CN)] (2). A solution ( $5 \mathrm{~mL}$ ) of $\mathrm{MeCN}: \mathrm{MeOH}=1: 1$ containing $\mathrm{CdCl}_{2} \cdot 2.5 \mathrm{H}_{2} \mathrm{O}(30.0 \mathrm{mg}, 0.11 \mathrm{mmol})$ was layered carefully to avoid possible mixing with a chloroform solution $(5 \mathrm{~mL})$ of $\mathbf{L}$ $(25.0 \mathrm{mg}, 0.06 \mathrm{mmol})$. After standing at room temperature for 3 day, colorless crystals suitable for X-ray analysis were obtained at the wall of glass tube. The crystals were filtered and washed rapidly with acetonitrile and diethyl ether (yield 53\%). mp $187-189^{\circ} \mathrm{C}$ (decomp.). IR ( $\left.\mathrm{KBr}, v, \mathrm{~cm}^{-1}\right) 3560$ (w, br), $2933(\mathrm{w})$, 1620(w), 1584(w), 1507(s), 1464(m), 1381(s), 1319(s), 1263(s), 1183(w), 1106(vs), 1050(s), 951(m), 829(m), 755(m). [Cd(L) $\mathrm{Cl}_{4}$ ] Anal. Calcd for $\mathrm{C}_{26} \mathrm{H}_{28} \mathrm{CdCl}_{4} \mathrm{~N}_{2} \mathrm{O}_{5}: \mathrm{C}, 44.44, \mathrm{H}, 4.02, \mathrm{~N}$, 3.99. Found: C, 44.08, H, 3.95, N, 4.12\%.

$\mathrm{X}$-ray crystallography. Single crystal diffraction data of $\mathbf{2}$ were collected on a Bruker Smart diffractometer equipped with a graphite monochromated $\operatorname{Mo~} \mathrm{K} \alpha(\lambda=0.71073 \AA)$ radiation source and a CCD detector. Crystals were isolated from mother liquor and immediately immersed in paratone oil and then mounted. The 45 frames of two dimensional diffraction images were collected at $173 \mathrm{~K}$ and processed to obtain the cell parameters and orientation matrix. A total of 1271 frames of twodimensional diffraction images were collected, each of which was measured for $5 \mathrm{sec}$. Decay was monitored by 50 standard data frames measured at the beginning and end of data collection. The crystal showed no significant decay. The frame data were processed to give structure factors using the SAINT-plus. ${ }^{12}$ Empirical absorption corrections were applied to the data sets using the SADABS..$^{13}$ The structure was solved by direct methods and refined by full matrix least squares methods on $F^{2}$ for all data using SHELXTL software. ${ }^{14}$ The solvent molecules are disordered with occupancies of 0.5 or 0.25 obtained by the refinement of their site occupancy factors. All thermal parameters of the solvent molecules were refined using ISOR and DFIX commands because their thermal parameters became unreasonably large or small. The non-hydrogen atoms were refined anisotropically. The hydrogen atoms were placed in calculated positions and refined with a riding model with the exception of the hydrogens of solvent water molecules, which were located in difference electron density maps and refined with a riding model. Crystallographic data and structural refinement data for $\mathbf{2}$ is summarized in Table 1.

Acknowledgments. Following are results of a study on the "Human Resource Development Center for Economic Region Leading Industry" Project, supported by the Ministry of Education, Science \& Tehnology (MEST) and the National Research Foundation of Korea (NRF).

Supplementary Material. Supplementary crystallographic data associated to complex $\mathbf{2}$ have been deposited at the Cambridge Crystallographic Data Centre, CCDC No. 780627. Copies of the data can be obtained free of charge on application to CCDC, 12 Union road, Cambridge CB2 1EZ, UK (fax: +44 1223 336033; e-mail: deposit@ccdc.cam.ac.uk), or electronically via www.ccdc.cam.ac.uk/perl/catreq.cgi.

Supporting Information. Supplementary Tables, Figure, and 
TGA of complex $\mathbf{2}$ and figures of complexes $\mathbf{1 a}$ and $\mathbf{1 b}$ are available via the internet at http://www.kcsnet.or.kr/bkcs.

\section{References}

1. Goldberg, I. Complexes of Crown Ethers with Molecular Guests, in Inclusion Compounds; Atwood, J. L., Davies, J. E. D., MacNicol, D. D., Eds.; Academic Press: London, 1984; Vol. 2, p 261.

2. (a) Gokel, G. W. Crown Ethers and Cryptands; Stoddart, J. F., Ed.; The Roal Society of Chemistry: Cambridge, 1994. (b) Dalley, N. K. Synthetic Multidentate Macrocyclic Compounds; Izatt, R. M., Christensen, J. J., Eds.; New York Academic Press: New York, 1978; p 270. (c) Hilgenfeld, R.; Saenger, W. Top. Curr. Chem. 1982, 101, 1. (d) Vögtle, F.; Sieger, H.; Müller, W. M. Top. Curr. Chem. 1981, 98, 107. (e) Truster, M. R. Struct. Bonding (Berlin) 1973, 16, 71. (f) Tsukube, H. Cation Binding by Macrocycles; Inoue, Y., Gokel, G. W., Eds.; Marcel Dekker: New York, 1990.

3. (a) Pedersen, C. J. J. Am. Chem. Soc. 1967, 89, 2495. (b) Pedersen, C. J. J. Am. Chem. Soc. 1967, 89, 7077. (c) Timko, J. M.; Moore, S. S.; Walba, D. M.; Hiberty, P. C.; Cram, D. J. J. Am. Chem. Soc. 1977, 99, 4207. (d) Braga, D.; Gandolfi, M.; Lusi, M.; Paolucci, D.; Polito, M.; Rubini, K.; Grepioni, F. Chem. Eur. J. 2007, 13,5249 .

4. (a) Metz, B.; Rosalky, J. M.; Weiss, R. J. Chem. Soc., Chem. Commun. 1976, 533. (b) Schultz, R. A.; Schelgel, E.; Dishong, D. M.; Gokel, G. W. J. Chem. Soc., Chem. Commun. 1982, 242. (c) Schultz, R. A.; White, B. D.; Dishong, D. M.; Arnold, K. A.; Gokel, G. W. J. Am. Chem. Soc. 1985, 107, 6659. (d) Tümmler, B.; Maass,
G.; Weber, E.; Wehner, W.; Vögtle, F. J. Am. Chem. Soc. 1977, 99, 4683. (e) Vögtle, F.; Sieger, H.; Müller, W. M. Top. Curr. Chem. 1981, 98, 107.

5. (a) Saenger, W.; Suh, I. H.; Weber, G. Israel J. Chem. 1979, 18, 253. (b) Weber, G.; Saenger, W. Acta Crystallogr. Sect. B 1979, 36, 424. (c) Pickardt, J.; Wiese, S. Z. Naturforsch. B 2000, 55, 971. (d) Weber, G.; Saenger, W. Acta Crystallogr. Sect. B 1979, 35, 1346.

6. (a) Vögtle, F.; Weber, E. Angew. Chem. Int. Ed. Engl. 1979, 18, 735. (b) Saenger, W.; Brand, H. Acta Crystallogr. Sect. B 1979, 35, 838. (c) Tümmler, B.; Maass, G.; Vögtle, F.; Sieger, H.; Heimann, U.; Weber, E. J. Am. Chem. Soc. 1979, 101, 2588.

7. (a) Yoon, I.; Lee, Y. H.; Jung, J. H.; Park, K.-M.; Kim, J.; Lee, S. S. Inorg. Chem. Commun. 2002, 5, 820. (b) Brodersen, K.; Zimmerhackl, J. Z.Naturforsch. B 1991, 46, 1.

8. Park, K.-M.; Moon, S.-T.; Kang, Y. J.; Kim, H. J.; Seo, J.; Lee, S. S. Inorg. Chem. Commun. 2006, 9, 671.

9. Iwamoto, R.; Wakano, H. J. Am. Chem. Soc. 1976, 98, 3764.

10. Bondi, A. J. Phys. Chem. 1964, 68, 441.

11. Berry, S. M.; Bebout, D. C. Inorg. Chem. 2005, 44, 27 and therein references.

12. Bruker, SMART (ver. 5.625) and SAINT-plus (ver. 6.22): Area Detector Control and Integration Software; Bruker AXS Inc.: Madison, Wisconsin, 2000.

13. Bruker, SADABS (ver. 2.03): Empirical Absorption and Correction Software; Bruker AXS Inc.: Madison, Wisconsin, 1999.

14. Bruker, SHELXTL (ver. 6.10): Program for Solution and Refinement of Crystal Structures; Bruker AXS Inc.: Madison, Wisconsin, 2000. 